\title{
In Memory of
}

Frederic C. Shorter

(1923-2012)

We are deeply saddened that Frederic C. Shorter passed away at his home in Seattle, Washington, on February 21, 2012.

Frederic C. Shorter, together with Nusret Fişek, played a key role in the establishment of demography as a discipline in Turkey. This role, as important as it is, constitutes part of a broader intellectual contribution; indeed, Shorter's life story parallels the development of demography and the social sciences in Turkey, as well as in the Middle East. Students of demography and of the larger social sciences are all grateful to him as a scholar, mentor, and friend.

Frederic C. Shorter received his Ph.D in Economics at Stanford University in 1957. He taught at UCLA, the University of North Carolina, and Princeton University; he was a visiting professor at METU, Hacettepe, and Boğaziçi Universities. He was a consultant to TURKSTAT (Turkish Statistical Institute), and a research advisor at İstanbul University. He worked in the Population Council in New York. He undertook consultancies and regional representations for the UN, Harvard University, the Population Council, and the Ford Foundation, and worked in Bangladesh, Egypt, and Turkey. He settled in Canada during his last years, maintaining also a home in Seattle.

His involvement in our region goes back to the 1960s. A bright, disciplined and hard-working economist, he came to Ankara as a program advisor in the social sciences for the Ford Foundation in 1966. He met Nusret Fişek, and a life-long friendship and struggle towards a common goal began immediately. Shorter noted in 1992 that he became deeply involved in demographic research in Turkey, mainly because of Fişek and his sincere enthusiasm for developing scientific knowledge in the country. ${ }^{1}$

Shorter's first work on Turkish demography, which was a collaborative study with Paul Demeny, was an important milestone in demograph-

Frederic C. Shorter, "Dostum Nusret Fişek," Prof. Dr. Nusret H. Fişek Için Yazdilar (1992), http://www. fisek.org.tr/083.php. 
ic research; it introduced new techniques to correct age-misreporting in Turkish censuses, as well as for measuring fertility and mortality levels from incomplete data, producing a contemporary as well as historical picture of the trends, going back to $1935 .{ }^{2}$ The book was published both in Turkish and English in the same volume by İstanbul University. The translators, Belgin Tekçe and Samira Berksan (Yener), had to create new Turkish words for some demographic terminology, which are still in use. Fişek and Shorter must have developed their relationship during the process of writing this work, since they both were concerned about high mortality and fertility levels in the country and their measurement. ${ }^{3}$

Nusret Fişek established the Institute of Population Studies at Hacettepe (HIPS), Ankara, in 1967 and became its first director. Shorter not only taught at the graduate program of HIPS, but was also actively involved in the institute's training and research activities. The quality of the students in the graduate program was quite high, partly because Fişek and Shorter provided generous scholarships from the Ford Foundation to every graduate student. They also collaborated actively to send two graduates for doctoral study to demographic centers in the US every year. Shorter continued this mission, later trying to find funds for graduate students to continue their education when their funds were cut off during the politically difficult years of the 1970s.

The same year, in 1967, Shorter conducted the institure's first field research on fertility and family planning with the help of its staff. ${ }^{4} \mathrm{~A}$ year later, Fişek and Shorter organized the first Turkish Demography Conference in İzmir, on February 21-24, 1968. The proceedings were published with editorials by Shorter and Bozkurt Güvenç. ${ }^{5}$ In the preface, they stated that " $[\mathbf{t}]$ his was an unusual conference in that it marked the establishment, or at least the recognition, of a new discipline and profession in Turkey, namely demography."6

2 Paul Demeny and Frederic C. Shorter, Estimating Turkish Mortality, Fertility, and Age Structure/Türkiye'de Olümlülük, Doğurganlık ve Yaş Yapısı Tahminleri, trans. S. Berksan (Yener) and Belgin Tekçe (Istanbul: Istanbul Üniversitesi, Iktisat Fakültesi Yayını, 1968).

3 Nusret Fişek conducted several local surveys on maternal and child mortality when he was the Director of the Refik Saydam School of Public Health (Hıfzısihha Enstitüsü) in 1958-1960. Later, he initiated the 1963 Population Survey and was effective in passing two important laws, namely the Law on the Socialization of Health Services (1961) and the Law on Population Planning (1965) during his tenure as Undersecratary of the Ministry of Health. "Ögeçmiş: Prof. Dr. Nusret Hasan Fişek (1914-1990)," Fişek Enstitüsü, last http://www.fisek.org.tr/084.php.

4 Ferhunde Özbay and Frederic C. Shorter, "Fertility and Family Planning in the Etimesgut Rural Health Region," in Turkish Demography: Proceedings of a Conference, eds. Frederic Shorter and Bozkurt Güvenç (Ankara: Hacettepe University Publications, 1969).

5 Frederic C. Shorter and Bozkurt Güvenç, eds., Turkish Demography: Proceedings of a Conference (Ankara: Hacettepe University Publications, 1969).

6 The paragraph continues to acknowledge earlier individual studies on population: "This stage could 
The 1960s were a period when several nation-wide surveys were conducted and techniques of survey analysis were acquired in Turkey. The first nation-wide demographic survey was conducted by the Population Council experts on behalf of the Turkish Ministry of Health in 1963. Fişek and Shorter decided to conduct the next one with the HIPS's graduate students and the rather limited number of institute employees in 1968. It was a challenging task since none of the organizers had experience with conducting a nation-wide survey, and the computer facilities were naturally rather primitive at that time. The success of the 1968 Survey owes much to Shorter who worked hard on the computer programming of the data, every night from 22:00 to 8:00, in the computer center of the State Water Works, one of the first computer facilities in Turkey, since HIPS was able to get permission to use their mainframe computer only during the night hours.

Shorter was my MA thesis advisor at HIPS. He was not only my advisor but also my mentor in all aspects of my professional career. I learned numerous things related to my profession from him, including self-discipline and hard work, during the thesis-writing process. Later in my life, I witnessed many other students receiving generous help from him, as I had during my training in demography. He made the students work hard, but in fact he worked even harder himself. In almost all of the collaborative work with young professionals, Shorter put their names first, as primary author, instead of his own name. We co-authored three articles, and in all of them, I think, he deserved to be the first author, including the one that came out of my thesis work, even though each time he insisted to put my name first.

Fişek and his team at HIPS conducted the second nation-wide survey in 1973. Unfortunately, Hacettepe University's administration terminated Fişek's tenure at HIPS soon after this survey. He was still at Hacettepe University and continued to be the Director of the Public Health Institute, but his formal connection with HIPS ended. Shorter and the core group of young demographers began to meet informally in Fişek's office in order to discuss which new areas of research needed to be explored in demography. At that time, the National Research Council (in the US) had decided to support publications on the state of the art of population research in various countries. Fişek thought that a team should be formed for the panel on Turkey, under Shorter's leadership. Miroslav Macura, who had come as a visiting scholar to HIPS during the

not have been reached without the earlier work of economists and statisticians in Turkey, such as Ömer Celal Sarç, Haluk Cillov, Kenan Gürtan and Erol Tümertekin and of Doçent Orhan Türkay." Ibid., v. 
early 1970s, agreed to contribute to this work as well. Sevinç Kavadarlı, Samira Yener and I, as young followers of the founders, agreed to help Shorter and Macura to write a report on demographic trends in Turkey. ${ }^{7}$ Shorter again insisted that our names must be among the authors. We all rejected this offer and, appreciating its scholarly value, decided to translate it into Turkish. ${ }^{8}$ The analysis covered the period from 1935 to 1975 and remained an important source for students of demographic dynamics in Turkey for a long time.

Fişek and Shorter, as the founders of the discipline of demography in Turkey, envisioned demographic studies as an integral part of the social sciences in the country. Throughout their life, together or separately, they worked toward that goal. Nusret Fişek's long-term aim was to establish an organization like TÜBITAK, ${ }^{9}$ for the social sciences. For that purpose, together with the Social Science Association, HIPS organized the first social science symposium under the title"The Development of Social Science Research in Turkey" in February 1970. The conference proceedings were published by HIPS in 1971. Unfortunately, the goal of the establishment of a social science organization similar to TÜBİTAK was not realized in the political context of the period.

Years later, in 1985, when the second symposium on the development of the social sciences was held by the Turkish Social Science Association, "demographic research" was included as a separate discipline, along with psychology, sociology, anthropology, political science, public administration, urban studies, and history. In the demographic research session, the first two presentations were given by Fişek and Shorter. Actually, Shorter could not attend the meeting and sent the Turkish translation of one of his brilliant studies on "The Population of Turkey after the War of Independence." ${ }^{10}$ This article remains one of the most significant and comprehensive analyses of the ways in which demographic trends are inextricably entangled with society, economy, politics, and history. Both of them probably were very proud to see the recognition of demographic studies along with other disciplines of the social sciences. It had

7 Frederic C. Shorter and Miroslav Macura, "Trends in Fertility and Mortality in Turkey, 1935-1975," (Washington DC: National Research Council (U.S.) Committee on Population and Demography. Panel on Turkey, 1982).

8 Türkiye'de Nüfus Artışı (1935-1975), trans. Sevinç Kavadarlı, Ferhunde Özbay, and Samira Yener (Ankara: Yurt Yayınlari, 1983).

9 Türkiye Bilimsel ve Teknolojik Araştırma Kurumu (TÜB|TAK) [The Scientific and Technological Research Council of Turkey], last http://unw.tubitak.gov.tr/.

10 Frederic C. Shorter, "The Population of Turkey after the War of Independence," International Journal of Middle East Studies 17, no. 4 (1985). The Turkish version is: "Cumhuriyetin Ilk Yillarında Nüfus Yapısı ve Sosyo-Ekonomik Deł̧işmeye Etkisi," in Türkiye'de Sosyal Bilim Araştırmalarının Gelişimi, ed. Sevil Atauz (Ankara: Türk Sosyal Bilimler Derneği, 1986). 
not been an easy task, and they had worked hard to reach this goal. I will relate a few more stories about Shorter's efforts towards this goal.

The late 1970s and early 1980s were difficult years for social scientists in Turkey. Egypt seemed a promising and leading country in the region of West Asia and North Africa. Hence, the Population Council decided to open a regional office in Cairo, as had some other international institutions, such as the International Development Research Center (IDRC). Shorter accepted the offer of the Population Council to become the Senior Representative for the West Asia and North Africa Regional Office in Cairo in 1978. The first task he undertook was to create a framework called the Middle East Research Awards (MEAwards) program, which proved to be a critical step in developing research capacity and fostering interdisciplinarity in the region for years to come. The primary aim of the program was to strengthen the capacity of regional researchers to study problems related to population and development, broadly defined, through research awards, seminars, workshops, technical assistance, and fellowships. Over the years, it came to include an impressive network of scholars and acquired a substantial reputation for excellent research.

The funds that the MEAwards offered directly to researchers were modest (less than USD 30,000 and most often around USD 10,00020,000 ), but they rapidly became a major source of funding for independent social science research in the region, supporting a wide variety of significant projects, including doctoral work. It was a highly competitive program, since in each cycle a limited number of proposals were selected among all the applicants from the countries of West Asia and North Africa. An interdisciplinary advisory committee of scholars, selected from different countries of the region for two-year terms, read the proposals and made the selection of the awardees. The program also helped along the integration and communication of social scientists in the Middle East, and important comparative studies were accomplished through this network.

Hundreds of social scientists from Turkey, as well as other countries of the region, benefited from the project awards and learned how to write research proposals, conduct field research, and write publishable work in the process. Shorter read and helped all the proposals coming to MEAwards twice a year, but never took part in selecting them. From the outset, Shorter believed that researchers from the region should set their own agenda and monitor their own research priorities. ${ }^{11}$

11 The program was evaluated very positively by external reviewers several times. The preface of the second evaluation stated: "MEAwards' founding director, Frederic Shorter, formulated its vision: providing assistance to promising social scientists, without imposing agendas, and remaining open to 
Concurrently, he was involved in research in Egypt, Jordan, and Syria. He worked on a study of child health in the context of family and community dynamics in an informal neighborhood of Cairo; ${ }^{12}$ on child mortality in squatter areas of Amman; ${ }^{13}$ and on demographic measures of inequality in Damascus. ${ }^{14}$ He established new but strong friendships in the region, such as with Huda Zurayk, a Lebanese bio-statistician and public health expert, and with Seteney Shami, an anthropologist from Jordan. Together with them, Shorter organized workshops and seminars in different parts of the region. After Shorter left Cairo, they became the regional representatives of the Population Council, consecutively, and continued to support the goals of the MEAwards.

Shorter was a meticulous researcher, always interested in building a solid technical basis for analysis, and intrigued early on by the possibilities that the newly emerging computer technology offered. He developed his programming skills so fast and so far that he produced a program package for population projections in 1974. Later on, two programmers joined him, and the final work was published with a manual, co-authored with Robert Sandek and Yvette Bayoumy, from the Population Council. ${ }^{15}$ Shorter made available a Turkish translation of the program as well. It became a popular program for projections and was re-issued several times, with some new additions. The last edition of the program was released in 1998.

In 1989, he retired from his post at the Population Council in Cairo, came back to Turkey, settled in İstanbul, and began to train new generations and work with Turkish data. Unfortunately, the following year, in 1990, Nusret Fişek passed away. The last time we visited him in the hospital, Fişek warned us that child mortality needed to be lowered further, and that we had to work hard to produce new publications on Turkish demography.

expanded boundaries for definition of population studies. Thus while keeping close links with international scholarship, MEAwards has maintained a unique regional character and a high degree of relevance and responsiveness to emerging issues." Shahnaz J. Rouse, Middle East Research Awards Program Impact and Future(S): A Fonward Looking Evaluation, Regional Papers (Giza: Population Council, 2001).

12 Belgin Tekçe et al., A Place to Live: Families and Child Health in a Cairo Neighborhood (Cairo: American University in Cairo Press, 1994).

13 Belgin Tekçe and Frederic C. Shorter, "Determinants of Child Mortality: A Study of Squatter Settlements in Amman," Population and Development Review 10, Supplement: Child Survival: Strategies for Research(1984).

14 Frederic C. Shorter, "Demographic Measures of Inequality and Development," in Population Factors in Development Planning in the Middle East, eds. Frederic C. Shorter and Huda Zurayk (Cairo: The Population Council, 1985).

15 Frederic C. Shorter et al., Computational Methods for Population Projections: With Particular Reference to Development Planning, 3rd ed. (New York: The Population Council, 1998). 
In 1993, Shorter began to work as a consultant to the President's Office for Population and Demographic Statistics of TURKSTAT, which at that time was called the State Institute of Statistics (SIS), and convinced them to produce a one-percent sample of the 1990 census to be used by researchers. In fact, he did most of the technical work with the help of competent statisticians, such as Meryem Demirci of SIS, Later, they produced a five-percent sample of the İstanbul population census as well. It was a revolutionary step for a demographer to be able to analyze the census raw data. I am deeply grateful to him for such an initiative.

Shorter was a faithful friend and never forgot Nusret Fişek. He wrote in his notes to "Dostum Nusret Fişek" (My friend Nusret Fişek): "A few months before he passed away he suggested to me and some others that a new up-to-date book should be written on Turkish demography, since the last comprehensive book was in 1982" (by Shorter and Macura, and it covered the 1935-1975 period). Shorter took this suggestion as his friend's last will. He continued: "An opportunity to fulfill his request came to me while I was working as a consultant at the SIS. A small team was organized at the SIS. For two years we studied all the available demographic data and wrote a new book: "The Population of Turkey, 1923-1994: Demographic Structure and Development, with Projections to the Mid-21 ${ }^{\text {st }}$ Century." ${ }^{16}$ It is an official publication, so you will not find a personal dedication to Dr. Nusret Fişek in the book. For me, personally, that work was done in his honor." ${ }^{17} \mathrm{He}$ did not put his name on the book either. It was a publication of the SIS and a masterpiece in Turkish demography.

Shorter also worked as a research advisor at the Institute of Child Health at Çapa Medical School at İstanbul University. The director of the Institute, Olcay Neyzi, a distinguished pediatrician, became a valued colleague and friend, as was the case with Fişek. They too shared the goal of improving mother and child health and accurately measuring child mortality. He devoted many hours to the institute staff, and together they produced a number of studies on infant and child mortality, including one that used the innovative method of determining deaths from burial records. ${ }^{18}$ In 1992, upon recommendation of the Child Health Institute,

16 DIE, Türkiye Nüfusu, 1923-1994: Demografi Yapısı ve Gelişimi - 21. Yüzyll Ortasına Kadar Projeksiyonlar (Ankara: Devlet istatistik Enstitüsü, 1995).

17 Shorter, "Dostum Nusret Fişek."

18 Such as, Ayşen Bulut et al., "Perinatal, Neonatal, and under-5 Mortality in Istanbul Based on Representative Samples of Burial Records," in Measurement of Maternal and Child Mortality, Morbidity and Health Care: Interdisciplinary Approaches, ed. J. Ties Boerma (Liege, Belgium: International Union for the Scientific Study of Population, Ordina Press, 1992); Cülbin Cökçay and Frederic C. Shorter, "Who 
he received an Honorary Doctorate in Health Sciences from İstanbul University.

Shorter had three main goals in his profession: supporting health studies, achieving accurate demographic analysis by using up-to-date measurement techniques, and promoting demography as an interdisciplinary field in the social sciences. I think, he accepted the offer to teach in the graduate program of the Sociology Department at Boğaziçi University to fulfill his third goal. The members of the department at that time were all good friends of his, and almost all had been involved in the MEAwards program, either as awardees or members of the advisory committee. ${ }^{19}$ He taught demography and continued to produce important social-science-oriented demographic papers during this period. Çağlar Keyder and Ayşe Öncü from the Sociology Department at Boğaziçi University were also the editors of New Perspectives on Turkey at that time, and Shorter valued the journal very much and published three historically and socially informed articles in it. ${ }^{20}$

Frederic Shorter was always open to new modes of analysis and research techniques, while remaining committed to viewing demographic dynamics as an inextricable part of social issues, economics, and politics. In his article entitled "The Crisis of Population Knowledge in Turkey," he stated: "To learn how the population by its own actions, rather than by acts of the state, was able to realize the low fertility levels that is perceived to be good life in Turkey, it seems to be necessary to study culture, and to make use of ethnographic methods." ${ }^{21}$ His more recent studies utilized a cultural perspective, as he envisaged the next necessary step in fertility studies. ${ }^{22}$

Students of the social sciences as well as demography will certainly feel his loss deeply.

\section{Ferhunde Özbay}

Boğaziçi University

Lives with Whom in Istanbul?," New Perspectives on Turkey, no. 9 (1993).

19 For example, Çaglar Keyder was one of the earliest awardees of the MEAwards and produced his well-known article on rural transformation from his project on agricultural development and seasonal migration. See Çağlar Keyder, "Paths of Rural Transformation in Turkey," Journal of Peasant Studies 11 , no. 1 (1983).

20 Gökçay and Shorter, "Who Lives with Whom in Istanbul?"; Frederic C. Shorter, "The Crisis of Population Knowledge in Turkey," New Perspectives on Turkey, no. 12 (1995); "Turkish Population in the Great Depression," New Perspectives on Turkey, no. 23 (2000).

21 "The Crisis," 27.

22 See, for example, Zeynep Angın and Frederic C. Shorter, "Negotiating Reproduction and Gender During the Fertility Decline in Turkey," Social Science and Medicine 47, no. 5 (1998). 


\section{Bibliography}

\section{Books}

\section{Authored}

(with Robert Sendek and Yvette Bayoumy). Computational Methods for Population Projections: With Particular Reference to Development Planning. Multi-language $3^{\text {rd }}$ ed. New York: The Population Council; HPN Technologies inc. [1995], 1998 [original edition 1974, additional printings and supplements, 1979, 1987, 1994; Software release 11.0].

(with Belgin Tekçe and Linda Oldham). A Place to Live: Families and Child Health in a Cairo Neighborhood. Cairo: American University in Cairo Press, 1994.

The Decline of Infant and Child Mortality: Estimates from the Turkish Census, Regional Papers. Cairo: The Population Council, Regional Office for West Asia and North Africa, 1989.

(with Huda Zurayk). The Social Composition of Households in Arab Cities and Settlements: Cairo, Beirut, Amman, Regional Papers. Cairo: The Population Council, 1988 [Arabic translation, 1990].

(with J.L. Evans, G.A Lamb, and N. Murthy). Women and Children in Poverty: Reproductive Health and Child Survival. New York: The Ford Foundation, 1987.

(with Miroslav Macura). Türkije'de Nüfus Artışı (1935-1975). Translated by Sevinç Kavadarh, Ferhunde Özbay and Samira Yener. Ankara: Yurt Yayınları, 1983.

(with Miroslav Macura). "Trends in Fertility and Mortality in Turkey, 1935-1975." Washington DC: National Research Council (U.S.) Committee on Population and Demography. Panel on Turkey, 1982.

(with Allan C. Hill and John Bongaarts). Intermediate Variables in Fertility Analysis: A Practical Guide, Regional Papers. Cairo: The Population Council, Regional Office for West Asia and North Africa, Cairo, 1979.

(with Paul Demeny). Estimating Turkish Mortality, Fertility, and Age Structure / Türkiye'de Olümlülük, Doğurganlik ve Yaş Yapısı Tahminleri. Translated by S. Berksan (Yener) and Belgin Tekçe. Istanbul: İstanbul Üniversitesi, Íktisat Fakültesi Yayını, 1968.

(with John F. Kolars, Dankwart A. Rustow, and Oktay Yenal). Four Studies on the Economic Development of Turkey, Princeton Studies on the near East Series. London: Frank Cass, 1967.

\section{Edited}

(with Huda Zurayk). Population Factors in Development Planning in the Middle East. Cairo: The Population Council, 1985.

(with Bozkurt Güvenç). Turkish Demography: Proceedings of a Conference. Ankara: Hacettepe University, 1969 [Turkish translation, 197].

\section{Selected Articles}

"Turkish Population in the Great Depression." New Perspectives on Turkey, no. 23 (2000): 103-124.

(with Zeynep Angın). "Negotiating Reproduction and Gender During the Fertility Decline in Turkey." Social Science and Medicine 47, no. 5 (1998): 555-564.

(with Zeynep Angın). "A View from Turkey: Men as Well as Women." Health Transition Review 6, no. 1 (1996): 101-102.

"The Crisis of Population Knowledge in Turkey." New Perspectives on Turkey, no. 12 (1995): 1-31.

"Aile" [Family]. In Istanbul Ansiklopedisi, 144-145. Istanbul: Tarih Vakfi, 1993.

(with Gülbin Gökçay). "Who Lives with Whom in Istanbul?" New Perspectives on Turkey, no. 9 (1993): 47-73. (with, Gülbin Gökçay, Ayşen Bulut, Olcay Neyzi, and Füsun Kayatürk). "İstanbul'da 5 Yaş Altı Çocukların Olümlerinin Epidemiyolojisi [An Epidemiological Evaluation of under-5 Mortality in Istanbul]." Turkish Journal of Medical Sciences, no. 16 (1992): 331-338.

(with Ayşen Bulut, Gülbin Gökçay, and Olcay Neyzi). "Perinatal, Neonatal, and under-s Mortality in Istanbul Based on Representative Samples of Burial Records." In Measurement of Maternal and Child Mortality, Morbidity and Health Care: Interdisciplinary Approaches, edited by J. Ties Boerma, $153-173$. Liege, Belgium: International Union for the Scientific Study of Population, Ordina Press, 1992.

"Dostum Nusret Fişek." Prof. Dr. Nusret H. Fişek için Yazdilar (1992), http://www.fisek.org.tr/083.php.

"Family Functioning and the Health of Women and Children: Theoretical Perspectives for the Regional 
Context." In Towards More Efficacy in Women's Health and Child Sunival Strategies: Combining Knowledge for Practical Solutions, Workshop Report, edited by Ismail Sirageldin and Robb Davis, 1-13. Baltimore: The Johns Hopkins University School of Hygiene and Public Health, Department of Population Dynamics, 1992.

(with Ayşen Bulut, Gülbin Gökçay, and Olcay Neyzi). "Istanbul'da Bebek ve Çocuk Ölümleri" [Infant and Child Mortality in Istanbul City]. The Turkish journal of Population Studies, no. 12 (1990): 5.18.

"The Welfare Implications of Infant Mortality Trends in Turkey." Journal of the Faculty of Economics and Administrative Sciences, Boğazį̧ University 4, no. 1 (1990): 89.103.

"Cairo's Leap Forward: People, Households and Dwelling Space." Cairo Papers in Social Science 12, Monograph 1 (1989).

"Cumhuriyetin Ilk Yıllarında Nüfus Yapısı ve Sosyo-Ekonomik Değişmeye Etkisi." In Türkiye'de Sosyal Bilim Araştırmalannın Gelişimi, edited by Sevil Atauz. Ankara: Türk Sosyal Bilimler Derneği, 1986.

"Demographic Measures of Inequality and Development." In Population Factors in Development Planning in the Middle East, edited by Frederic C. Shorter and Huda Zurayk, 59-72. Cairo: The Population Council, 1985.

"The Population of Turkey after the War of Independence." International Journal of Middle East Studies 17 , no. 4 (1985): $417-441$.

(with Belgin Tekçe). "Determinants of Child Mortality: A Study of Squatter Settlements in Amman." Population and Development Review 10, Supplement: Child Survival: Strategies for Research (1984): 257-280.

"Population Policy." Cairo Papers in Social Science 4, no. 2-3 (1981): 22-34.

"Croissance et inégalités au recensement de Damas / Inequality and Development as Shown in the Census of Damascus." Population 34, no. 6 (1979 [Published in English and Arabic, 1985]): 1067-1086. (with Ferhunde Ozbay and Samira Yener). "Accounting for the Trend of Fertility in Turkey." In Demographic Transition and Socioeconomic Development, 125-134. New York: Department of International Economic and Social Affairs, United Nations, 1979.

(with Belgin Tekçe). "The Demographic Determinants of Urbanization in Turkey, 1935-1970." In Turkey: Geographical and Social Perspectives, edited by Peter Benedict, Erol Tümertekin and Fatma Mansur, 281-294. Leiden: E.J. Brill, 1974.

"Estimates of Crude Birth Rates from Place-of-Birth Data; 67 Provinces, 1955-1965." Nüfus Yayınları Bülteni 3. no. 3 (1971): $3-8$.

(with Ferhunde Ozbay). "Turkey: Changes in Birth Control Practice, 1963 to 1968." Studies in Family Planning, no. 51 (1970 [Turkish translation, 1970]): 1-23.

"The Economics of Turkish Population Policy since the Founding of the Republic." Hacettepe Bulletin of Social Sciences and Humanities 1, no. 1 (1969): 58-66.

(with Ferhunde Ozbay). "Fertility and Family Planning in the Etimesgut Rural Health Region." In Turkish Demography: Proceedings of a Conference, edited by Frederic Shorter and Bozkurt Güvenç. Ankara: Hacettepe University Publications, 1969.

(with Nusret Fişek). "Fertility Control in Turkey." Demography 5, no. 2 (1968): 578-589.

"Information on Fertility, Mortality, and Population Growth in Turkey." Population Index 34, no. 1 (1968): 3.21.

"Military Expenditures and the Allocation of Development Resources." In Four Studies on the Economic Development of Turkey, 33.61. London: Frank Cass, 1967.

"The Application of Development Hypotheses in Middle Eastern Studies." Economic Development and Cultural Change 14, no. 3 (1966): 340-354.

"The Development of Entrepreneurship in Pakistan." American Economic Review 52, no. 2 (1962): 64-66.

"Planning Procedures in Pakistan." The Pakistan Development Review 1, no. 2 (1961): 1-14.

"Foodgrains Policy in East Pakistan." Public Policy, no. 9 (1959): 107-126.

"Food Imports and Economic Development in East Pakistan." Pakistan Economic journal 8, no. 1 (1958): 1-16.

"Jute Production Policies of India and Pakistan." Indian Economic Journal 3, no. 1 (1955): 18-50. 